\title{
THE EFFECT OF MARKETING CHANNELS AND PACKAGING ON BUSINESS SUCCESS IN STANDARD BUSINESSES IN THE CITY OF LHOKSUMAWE
} (Case Study on Internet Data Package Merchants)

\author{
Siswoyo Adi Wijaya ${ }^{1}$, Syarifah Hanum ${ }^{2}$, Muammar Khaddafi ${ }^{3}$ \\ Faculty of Economics and Business, Universitas Malikussaleh \\ E-mail: Khaddafi@unimal.ac.id
}

\begin{abstract}
The results of this study show. (1) The constant value (a) of 6.253 indicates the magnitude of the Business Success Variable (Y) if the Marketing Channel Variable (X1) and the Packaging variable (X2) are equal to zero. (2) It can be seen that the adjusted $R$ square value is 0.308 or $30.8 \%$. This shows that the Marketing Channel Variable (X1) and Packaging Variable (X2) can explain the Business Success Variable (Y) of 30.8\%, the remaining 69. 2\% (100\%-30.8\%) is explained by other variables outside this research model. (3)Testing the first hypothesis, it can be seen that tcount $(0,-404)<$ ttable $(-2.004)$, as well as the significance value of $0,689>0.05$, it can be concluded that the hypothesis first rejected, it meansVariable Marketing channel(X1) has no significant effect on Variable Business Success (Y). (4) Testing the second hypothesis, it can be seen that tcount $(3,934)>$ ttable $(2.004)$, and the significance value is $0.000<0.05$, it can be concluded that the second hypothesis is accepted, meaning thatVariable Packaging (X2) has a significant effect on the Business Success Variable (Y). (5) Testing the third hypothesis, it can be seen that Fcount $(7,894)>$ Ftable (3.33), and a significance value of 0,002<0.05, it can be concluded that the third hypothesis is accepted, meaning that Variable Marketing channel(X1), Variable Packaging (X2) has a significant effect simultaneously (simultaneously) on the Variable Business Success $(Y)$.
\end{abstract}

Keywords: Marketing channel, Packaging and Business Success

\section{BACKGROUND}

Business success can be indicated in five ways, namely the number of sales increases, production results increase, profits or profits increase, business development and growth develops quickly and satisfactorily. The measure of business success is being able to provide satisfaction to customers. The more customers who accept the products or services offered, the more satisfied they are, and this means that the strategy implemented has been quite successful.

Street vendors or commonly abbreviated as street vendors is a term to refer to vendors who use carts. In "etymology" or language, traders are usually defined as a type of work related to buying and selling. Traders are people who work by buying an item which is then resold at a higher price so that they benefit from the item. Along with the advancement and sophistication of technology, individuals experience major changes in terms of telecommunications and transactions. Most of the people choose to use electronic means and internet media as a medium for their activities. The use of cellular phones is also increasingly widespread, not only limited to communication via telephone but also used for communication via the internet.

Communicating using the internet network via cellular phones has become an inseparable part of people's daily lives. The use of the internet network on cellular phones is not limited only to the older generation, young people and children and the upper class, but has become a necessity for all groups. The older generation, young people, teenagers and adults are increasingly opening themselves up to obtain all forms of information regarding technological developments or other information through the internet. According to Kadiman (2013: 100) this is because cellular phones are not only the most effective means of communicating, but the internet network can also be part 
THE EFFECT OF MARKETING CHANNELS AND PACKAGING ON BUSINESS SUCCESS IN STANDARD BUSINESSES IN THE CITY OF LHOKSUMAWE

(Case Study on Internet Data Package Merchants)

Siswoyo Adi Wijaya, Syarifah Hanum, Muammar Khaddafi

of the user's lifestyle.

On the positive side, the informal sector of street vendors is a life belt that accommodates excess labor that is not accommodated in the formal sector (Usman, 2016), so as to reduce unemployment. The presence of street vendors in the city of lhoksumawe can also increase the vitality of the area they occupy and act as a liaison between the activities of one city service function and another. In addition, street vendors also provide services to people who are active around the location of street vendors, so that they get easy and fast service to get the goods they need. The accuracy of site selection is one of the factors considered by street vendors before opening their business.

According to Fandy Tjiptono (2012: 92) "marketing channels are places where businesses operate or where businesses carry out activities to produce goods and services that are concerned with the economic aspect." Meanwhile, according to Ujang Suwarman (2012: 280), "Location is a place of business that greatly influences a consumer's desire to come and shop". Location selection factors need to be considered by business owners in determining the location of their business, because business location is one of the business strategies. According to Fandy Tjiptono (2012: 92) the selection of a place or location of a business requires careful consideration of the following factors:

Accessibility, for example a location that is passed or easily accessible by public transportation facilities; Visibility, namely a location or place that can be seen clearly from normal viewing distances; Traffic, involves two main considerations: (a) The number of people passing by can provide a great opportunity for buying, namely buying decisions that often occur spontaneously, without planning, and or without going through special efforts; (b) Traffic congestion and congestion can also be a bottleneck; Spacious, comfortable, and safe parking space, both for twowheeled and four-wheeled vehicles; Expansion, namely the availability of a large enough space if there is an expansion in the future; Environment, namely the surrounding area that supports the products offered; Competition, namely the location of competitors. For example, in determining the location,

According to Kristanto (2011: 158) one of the most important factors that affect production costs and the ability of businesses to compete with other businesses is the location of the business. When a business evaluates various locations, the business must be able to consider every factor that can affect the attractiveness of each location.

With the limited location and the high cost of renting a location to sell, it creates innovations for entrepreneurship by using a car. Where the car is parked at the selected location and the back door is opened so that they can sell internet data packages. This is one of the entrepreneurial innovations that can minimize capital, become more practical and easily reach consumers. Selling on the street is also one of the attractions for consumers and this makes internet package entrepreneurs more efficient and makes it easier to determine the location. In addition to not having to pay a lot for renting a place of business, this business can also easily move locations. With the practicality of selling using a car, you can move from place to place to find a busy business location easily.

There are more and more people selling on the street, even only about 50 meters between one quota car and another, competing with each other to be the choice of consumers or internet enthusiasts. The number of businesses that have replaced outlets that sell internet packages permanently (fixed stations) into quota cars has led to the attraction of customers.

Product knowledge is a collection of various kinds of information about products, which include product categories, brands, product terminology, product attributes or features, product prices, and product beliefs. Product knowledge will be used by consumers to evaluate various alternatives and then determine an alternative choice that is considered to provide satisfaction. The experience and knowledge of the product will influence the next consumer's behavior, namely whether to repurchase the product or not. 
Several roadsides around Lhoksumawe City, there are parked cars with the activity of selling several brands of internet providers with various capacities and fairly cheap prices. open question "How do marketing channels and product packaging affect business success"?. The results of the pre-survey showed that 20 people said that the success of the business of Kali Lima traders in the city of Lhoksumawe was strongly influenced by the marketing channels and packaging of the goods sold by the respondents. Meanwhile, 5 people said that marketing channels and packaging had no effect on the success of their business.

\section{PREVIOUS RESEARCH}

Previous research is an attempt by researchers to find comparisons and then to find new inspiration for further research. In addition, previous studies help researchers to position research and show the originality of the research. In this section, the researcher includes various previous research results related to the research to be carried out, then makes a summary, both published and unpublished research. The following is a previous study that is still related to the theme that the author is studying.

1. Kevin Alberto 2019 Effect of packaging, price, promotion and location on business success. The results of the first hypothesis test showed that packaging (X1) was found to have a partially positive effect on business success (Y) in Bu Rudy's Sambal, so it can be said that increasing packaging (X1) can also increase business success (Y) Sambal Bu Rudy. This study supports research by Bakhtiari (2014) which states that packaging has a significant influence on business success. Likewise with Mustapha's research (2017) which states that packaging has a significant influence on business success. As well as research conducted by Setiawan and Harmon (2017) which states that packaging has a significant influence on business success.

2. Sumardy Saragih 2018 The Effect of Entrepreneurship Orientation and Marketing Channels on Business Success in Coffee SMEs in Purba District, Simalungun Regency. This study aims to analyze and determine the effect of entrepreneurial orientation and marketing channels on business success in coffee SMEs in Purba District, Kab. Simalungun. This research is a type of associative research that aims to analyze the effect of one variable with another variable. The population of this research is all entrepreneurs who are also owners of small and medium-scale coffee businesses (SMEs) in Purba District, Kab. Simalungun. The sampling method used the census method with a sample of 34 SMEs. Primary data was collected through questionnaires, secondary data was collected through literature study. This study uses descriptive analysis techniques and multiple linear analysis. The results showed that simultaneously and partially entrepreneurial orientation and marketing channels had a positive and significant effect on business success. The value of the coefficient of determination can be seen from the Adjusted R Square of 0.520 which means that $52.0 \%$ of the business success of Coffee SMEs in Purba District, Simalungun Regency can be explained by entrepreneurial orientation and marketing channels. While the remaining $48.0 \%$ can be explained by factors other than those studied in this study such as Market Orientation, ability to recognize opportunities and others. Simalungun Regency can be explained by its entrepreneurial orientation and marketing channels. While the remaining $48.0 \%$ can be explained by factors other than those studied in this study such as Market Orientation, ability to recognize opportunities and others. Simalungun Regency can be explained by its entrepreneurial orientation and marketing channels. While the remaining $48.0 \%$ can be explained by factors other than those studied in this study such as Market Orientation, ability to recognize opportunities and others.

3. Hanny Mariani 2018 The Effect of Marketing Strategy on the Success of Micro, Small and Medium Enterprises in the Culinary Sector in the East Bogor Region.This study aims to determine how much influence marketing strategy has on the success of micro, small and medium enterprises in the culinary field in the East Bogor area. This research was conducted from March to July 2016 and further research was carried out in December 
2017 to January 2018 in several micro-enterprises. small, and medium-sized culinary fields in the East Bogor area. The method used is a survey with a correlational approach. The data was collected using interviews and questionnaires. The validity test used the product moment formula and the reliability test used Cronbach's Alpha with the results of 0.926 for the marketing strategy instrument, and 0.926 for the business success instrument, meaning that it has a very high level of consistency (reliable). The population in this study is micro and small business actors, and middle class in the culinary field in the East Bogor area, totaling 96 business actors. Sampling using the Slovin formula with an inaccuracy level of 96 business actors. The data analysis technique used is the regression equation and hypothesis testing in the form of $t$-test. Based on the results of data analysis, it is known that there is an influence between marketing strategy on business success, this can be seen from the results of data analysis which shows the tcount value of 12.156 which is greater than ttable of 1.661 . In regression, there is an influence between marketing strategy on business success. There is a significant influence of marketing strategy with business success with a correlation coefficient of 0.619 . Thus, the research hypothesis is accepted, then the coefficient of determination (R2) is $38.3 \%$.

\section{IMPLEMENTATION METHOD}

3.1 Types and Sources of Data

3.1.1 Data Type

This research is a quantitative research, Quantitative data according to Sugiyono (2015) is data in the form of numbers or qualitative data that is numbered.

\subsubsection{Data Source}

Primary Data is a data source that directly provides data to data collectors. In this study, primary data in the form of data from questionnaires and interviews conducted by researchers.

Secondary data is a source that does not directly provide data to data collectors, for example through other people or through documents.

3.2 Data Collection Techniques

3.2.1 Questionnaire

Questionnaires or questionnaires are a number of questions or written statements about factual data or opinions relating to the respondent, which are considered facts or truths that are known and need to be answered by the respondent (Suroyo anwar 2009:168.). In this questionnaire, a closed question model will be used, namely questions that have been accompanied by previous alternative answers so that respondents can choose one of these alternative answers.

The data processing in this study used a Likert Scale.According to Sugiyono (2013:132), "Likert scale is used to measure attitudes, opinions and perceptions of a person or group of people about social phenomena".

In answering this Likert scale, the respondent only gives a mark, for example a checklist or a cross on the answer chosen according to the statement. The questionnaire that has been filled out by the respondent needs to be scored. The following is the weight of the assessment on the Likert scale.

\subsubsection{Interview}

According to Sugiyono (2015:231) interviews are data collection techniques if researchers want to conduct a preliminary study to find problems that must be investigated, but also if researchers want to know things from respondents more deeply. 
3.3 Population and Sample

3.3.1 Population

Sugiyono (2011: 90) suggests that population is a generalization area consisting of objects/subjects that have certain qualities and characteristics determined by researchers to be studied and then drawn conclusions. The population in this study was the population of street vendors selling packages in Lhoksumawe City, which amounted to 32.

\subsubsection{Sample}

In this study, the sampling technique used by the researcher is saturated sampling. Saturated sampling is a sampling technique when all members of the population are used as samples, or researchers who want to make generalizations with very small errors. According to (Sugiyono, 2010). Another term for a saturated sample is a census, where members of the population are sampled. Based on this explanation, the sample of this study were 32 street vendors with internet data packages in Lhoksumawe City.

\subsection{Definition of Variable Operations}

Definition of Variables According to Sugiyono (2013:58) the definition of a variable is:

"An attribute or nature or value of a person, object or activity that has a certain variation set by researchers to study and draw conclusions".

3.4.1 Independent Variables (Independent Variables)

The definition of independent variables according to Sugiyono (2013:39) is a variable that affects or is the cause of the change or the emergence of the dependent variable (dependent).

\subsubsection{Bound Variable (Developed Variable)}

The definition of the dependent variable according to Sugiyono (2013:39) is a variable that is influenced or becomes a result because of the independent variable.

\subsection{Data Analysis Techniques}

Data analysis is a desire to group, make a sequence, manipulate and abbreviate data so that it is easy to read and understand. In other words, data analysis activities are raw data that has been collected and needs to be categorized or divided into several categories or groups, abbreviated in such a way that the data can answer the problem according to the research objectives and can test hypotheses (Silaen and Widiyono, 2013).

\section{RESEARCH RESULTS}

\subsection{Partial t-test}

\begin{tabular}{|c|c|c|c|c|c|c|c|}
\hline & \multicolumn{3}{|r|}{ Coefficientsa } & \multirow[b]{3}{*}{$\mathrm{T}$} & \multirow[b]{3}{*}{ Sig. } & & \\
\hline \multirow[b]{2}{*}{ Model } & \multicolumn{2}{|c|}{$\begin{array}{l}\text { Unstandardized } \\
\text { Coefficients }\end{array}$} & \multirow{2}{*}{$\begin{array}{c}\text { Standardized } \\
\text { Coefficients }\end{array}$} & & & \multicolumn{2}{|c|}{$\begin{array}{c}\text { Collinearity } \\
\text { Statistics }\end{array}$} \\
\hline & B & Std. Error & & & & Tolerance & VIF \\
\hline 1 (Constant) & 6,253 & 2,424 & \multirow[b]{2}{*}{,- 060} & 2,580 & 0.015 & \multirow[b]{2}{*}{,998 } & \multirow[b]{2}{*}{1.002} \\
\hline $\begin{array}{l}\text { Channel_Ma } \\
\text { rketing_x1 }\end{array}$ & -.042 & 103 & & - & 689 & & \\
\hline $\begin{array}{l}\text { Packaging_x } \\
2\end{array}$ & ,544 & 138 & ,588 & 3,934 & , 000 & ,998 & 1.002 \\
\hline
\end{tabular}

a. Dependent Variables: Y_Success_Business 
THE EFFECT OF MARKETING CHANNELS AND PACKAGING ON BUSINESS SUCCESS IN STANDARD BUSINESSES IN THE CITY OF LHOKSUMAWE

(Case Study on Internet Data Package Merchants)

Siswoyo Adi Wijaya, Syarifah Hanum, Muammar Khaddafi

a. Hypothesis Testing the Effect of Marketing Channel Variables (X1) on Business Success Variables (Y)

The form of hypothesis testing based on statistics and curves can be described as follows:

Decision Making Criteria:

a) Accept H0 If tcount < ttable or -tcount > - ttable orvalue Sig. $>0.05$

b) Reject H0 If tcount ttable or -tcount - ttable orSig. $<0.05$

From table 4.11 , the tcount value is -0.404 . With $=5 \%$, ttable $(5 \% ; 32-2=30)$ the ttable value is 2.004 . From the description it can be seen that tcount $(-0.404)<$ ttable $(-2.004)$, thus also with a significance value of $0,689>0.05$, it can be concluded that the hypothesis first rejected, it means Variable Marketing channel (X1) has no significant effect on VariableBusiness Success (Y). This study is in accordance with Sumardy Saragih 2018 The Effect of Entrepreneurship Orientation and Marketing Channels on Business Success in Coffee SMEs in Purba District, Simalungun Regency.

b. Hypothesis Testing the Effect of Packaging Variables (X2) on Business Success Variables (Y), the form of hypothesis testing based on statistics and curves can be described as follows:

Decision Making Criteria:

1) Accept, If tcount $>$ ttable or -tcount $>$ - ttable orvalue Sig. $<0.05$

2) Reject, If tcount $<$ ttable or -tcount $<-$ ttable orSig. $>0.05$

From table 4.11 obtained tcount value of 3,934 With $=5 \%$, ttable $(5 \% ; 32-2=30)$ the value of ttable is 2.004 . From the description it can be seen that tcount $(3,934)>$ ttable (2.004), and the significance value is $0.000<0.05$, it can be concluded that the second hypothesis is accepted, meaning that Variable Packaging (X2) has a significant effect on the Business Success Variable (Y). This research is in line with research Kevin Alberto 2019 Effect of packaging, price, promotion and location on business success.

4.2 Simultaneous F Test

\begin{tabular}{|l|r|r|r|r|r|}
\hline Model & Sum of Squares & df & Mean Square & F & Sig. \\
\hline 1 Regression & 19,344 & 2 & 9,672 & 7,894 &, $002 b$ \\
Residual & 35,531 & 29 & 1,225 & & \\
Total & 54,875 & 31 & & & \\
\hline
\end{tabular}

a. Dependent Variables:Y_Success_Business

b. Predictors: (Constant), packaging_x2, marketing_channel_x1

The form of hypothesis testing based on statistics and curves can be described as follows: Decision Making Criteria:

a) If the calculated F value $>\mathrm{F}$ table or Sig. $<0.05$ then $\mathrm{Ha}$ is accepted and $\mathrm{H} 0$ is rejected.

b) If the value of F count $<\mathrm{F}$ table or Sig. $>0.05$ then Ha is rejected and $\mathrm{H} 0$ is accepted.

from table 4.12 obtained the value of Fcount of 7,894 With $=5 \%$, dk numerator : 3 , dk denominator : $32-2-1(5 \% ; 2 ; 29)$ obtained Ftable value of 3.33 From the description it can be seen that Fcount $(7,894)>$ Ftable (3.33), and a significance value of $0,002<0.05$, it can be concluded that the third hypothesis is accepted, meaning that Variable Marketing channel 
(X1), Variable Packaging (X2) has a significant effect simultaneously (simultaneously) on the Variable Business Success (Y).

\section{CONCLUSION}

1. Testing the first hypothesis, it can be seen that tcount $(-0.404)<$ ttable $(-2.004)$, as well as the significance value of $0,689>0.05$, it can be concluded that the hypothesis first rejected, it means Variable Marketing channel (X1) has no significant effect on VariableBusiness Success (Y).

2. Testing the second hypothesis, it can be seen that tcount $(3,934)>$ ttable $(2.004)$, and the significance value is $0.000<0.05$, it can be concluded that the second hypothesis is accepted, meaning that Variable Packaging (X2) has a significant effect on the Business Success Variable (Y).

3. Testing the third hypothesis, it can be seen that Fcount $(7,894)>$ Ftable (3.33), and a significance value of $0,002<0.05$, it can be concluded that the third hypothesis is accepted, meaning that Variable Marketing channel (X1), Variable Packaging (X2) has a significant effect simultaneously (simultaneously) on the Variable Business Success (Y).

\section{REFERENCES}

Algifari, 2010. Regression Analysis Theory, Cases and Solutions Second Edition. Yogyakarta: BPFE.

Alma, Buchory., and Saladin, Djaslim. 2010. Marketing Management: Practical Summary, Theory, Applications And Frequently Asked Questions. Bandung : CV. Linda Karya.

Andrianto, Rei \& Indrianita Anis. 2014. The Influence of Corporate Governance Structure and Debt Contracts on Earnings Management Practices. Proceedings of the XIII National Accounting Symposium. Purwokerto, Indonesia.

Assauri, Sofjan. 2012. "Strategic Management, Sustainable Competitive Advantage". Indonesia, Jakarta.

Daryanto. 2011. Marketing Management: Sari College. Bandung: One Nusa

Dhurup, M., Mafini, C. and Dumasi, T. (2014). The impact of packaging, price and brand awareness on brand loyalty: Evidence from the paint retailing industry. Acta Commercii 14(1), Art. \#194, 9 pages.

Danang, Sunyoto. (2013). Accounting Research Methodology. Bandung: PT Refika Aditama Member of Ikapi.

Fandy, Tjiptono. 2011. Marketing Strategy, Yogyakarta: Andi 2012. Marketing Strategy, ed. 3, Yogyakarta, Andi.

Geraldy Tambajong, 2013, The Effect of Marketing Mix on Yamaha Motorcycle Sales at PT. Sarana Niaga Megah Kerta Manado, EMBA Journal, Vol.1 No. 3 September 2013, p. 12911301.

Ghozali, Imam. 2016. Application of Multivariete Analysis With IBM SPSS 23 Program (8th Edition). VIII Printing. Semarang : Diponegoro University Publishing Agency.

Hartono, Hendry, et al. 2012. The Effect of Marketing Strategy on Increasing Sales in the Company" By Establishing Bina Nusantara University Alumni and Students as Objects Study. Management major. Bina Nusantara University.

Helmet, Dodot. 2012. About Reality. Meaning House.http://iinxsolihin16.blogspot.com/2012/07/definisi-success-inlife.html\#US1hMdnXinA Accessed On February 12, 2013

Kadiman, Irawan (2013), Development theory and indicators, Jakarta: Institute of State Administration of the Republic of Indonesia.

Kasmir, 2011, "Financial Report Analysis”, Raja Grafindo Persada: Jakarta.

------ 2013. Entrepreneurship. Publisher: Raja Grafindo, Jakarta. 
THE EFFECT OF MARKETING CHANNELS AND PACKAGING ON BUSINESS SUCCESS IN STANDARD BUSINESSES IN THE CITY OF LHOKSUMAWE

(Case Study on Internet Data Package Merchants)

Siswoyo Adi Wijaya, Syarifah Hanum, Muammar Khaddafi

Kristanto Hc, R Heru. 2011. Entrepreneurship (Entrepreneurship): Management Approach and Practice. First Edition, Graha Ilmu, Yogyakarta.

------ 2013. Industrial Ecology. Yogyakarta: Andi offset.

Kotler, Philip and Kevin Lane Keller, 2011. Marketing Management, Edition 13 Volumes 1 and 2, Translated: Bob Sabran, Erlangga, Jakarta.

------ 2012. Principles of Marketing. New Jersey: Prentice Hall.

2014: Principles of Marketing, 15th edition. New Jersey: Pearson Pretice Hall

Kapferer, Jean-Noel. 2012. The New Strategic Brand Management: Advanced Insights and Strategic Thinking fifth Edition. London: Kogan Page

Levens M. 2010. Marketing: defined, Explained, Applied. International Edition. Pearson (US): Prentice Hall.

Noersasongko, Edi. 2013. Analysis of the Effect of Entrepreneurial Individual Characteristics and Leadership Style on Business Ability and Business Success in Bank Businesses in Central Java. Doctoral Dissertation at the Fps University of Merdeka Malang.

Primiana, Ina, 2011, Mobilizing the Real Sector of SMEs and Industry, Alfabeta, Bandung.

Rangkuti, Freddy, Creative Promotion Strategy and Integrated Marketing Communication Case Analysis, Gramedia Pustaka Utama, Jakarta, 2010.

Situmorang, Syafizal Helmi. 2010. Data Analysis. Medan:USU Press.

----- 2013. Business: Planning and Development. First Edition. Medan: USU Press.

Sugiyono. 2010. Educational Research Methods Quantitative, Qualitative, and R\&D Approaches. Bandung: Alphabeta.

(2012). Statistics for Research. Bandung: Alphabeta.

2011. Quantitative, Qualitative and R\&D Research Methods. Bandung: Afabeta

2013. Business Research Methodology. Publisher : CV. Alphabet, Bandung.

Sudaryono, 2016. Marketing Management and Implementation Theory. Yogyakarta: ANDI

Sumarwan, Ujang. (2012). "Consumer behavior". Ghalia Indonesia Publisher, Jakarta.

Suryana. 2015. Entrepreneurship: Practical Guidelines, Tips and Processes Towards Success, Fourth Edition, Salemba Empat, Jakarta.

Suyatno Thomas, 2010. Fundamentals of Credit, Jakarta: PT Gramedia Pustaka Utama.

Sri Lestari, Dwi Arum, (2013). Redesign of Snack Product Packaging "Ameka Gorengan Super 2R", Semarang: Final Project of Semarang State University, pp 16,17,18,19,20.

Tjiptono, Fandy, 2014. Service Marketing- Principles, Applications, and Research, Andi Publisher, Yogyakarta

Tandio, Evan., Adib, Ahmad., and Wijayanti, Ani, (2013). Logo Design and Packaging Design for Dhisti Cookies as a Snack in the City of Solo, Surakarta: Journal of Petra Christian University and Sebelas Maret University, pages 2, and 4.

Usman, Ahmad, M \& M. 2016. The Influence of Competence, Compensation and Work Environment on Work Motivation in Sub-District Office Employees in Sungai Penuh City. Journal of Management and Public Research, 1(1), p. 1-11.

Wijoyo, 2009. Indonesian Dictionary, Balai Pustaka, Jakarta 